В. М. Нечипорук ${ }^{1}$, 3. М. Небесна ${ }^{2}$ О. В. Ковальчук ${ }^{1}$, Л. О. Пентюк ${ }^{1}$ М. М. Корда

\title{
УЛЬТРАСТРУКТУРНІ ЗМІНИ ПЕЧІНКИ ПРИ ЕКСПЕРИМЕНТАЛЬНІЙ ГІПЕРГОМОЦИСТЕЇНЕМІЇ НА ТЛІ ГІПО- ТА ГІПЕРТИРЕОЗУ
}

\author{
Ультраструктурні зміни печінки при \\ експериментальній гіпергомоцистеїнемії на тлі гіпо- \\ та гіпертиреозу \\ В. М. Нечипорук ${ }^{1}$, 3. М. Небесна ${ }^{2}$, О. В. Ковальчук ${ }^{1}$, \\ Л. О. Пентюк ${ }^{1}$ М. М. Корда ${ }^{2}$ \\ Вінницький національний медичний університет \\ імені М. І. Пирогова ${ }^{1}$ \\ Тернопільський національний медичний університет \\ імені І. Я. Горбачевського МОЗ України²
}

Резюме. Гормони щитоподібної залози відіграють вирішальну роль у підтриманні метаболічного гомеостазу протягом усього життя. Загальновідомо, що печінка та щитоподібна залоза тісно пов'язані між собою, при цьому тиреоїдні гормони відіграють важливу роль у ліпогенезі de novo, бета-окисненні жирних кислот, обміні холестеролу та вуглеводному обміні. Високий рівень циркулюючого гомоцистеїну (ГЦ) (гіпергомоцистеїнемія (ГГЦ)) $є$ незалежним фрактором розвитку атеросклерозу, індукує завершення клітинного циклу, пришвидшує процеси старіння, викликає апоптоз в ендотеліальних клітинах та нейронах.

Мета дослідження - встановити реорганізацію структурних компонентів печінки за умов змодельованої гіпергомоцистеїнемії, гіпер- та гіпотиреозу та при їх поєднаному впливові.

Матеріали і методи. Тіолактонову ГГЦ моделювали введенням тваринам екзогенного ГЦ у вигляді тіолактону в дозі 100 мг/кг маси тіла один раз на добу протягом 28 діб. Гіпертиреоз моделювали шляхом щоденного введення L-тироксину в дозі 200 мкг/кг протягом 21-ї доби, гіпотиреоз - шляхом щоденного введення мерказолілу в дозі 10 мг/кг упродовж 21-ї доби. Окремій групі тварин вводили L-тироксин і мерказоліл паралельно з ГЦ.

Результати. Встановлено, що за умов змодельованої ГГЦ, гіпо- та гіпертиреозу в печінці дослідних тварин спостерігаються розлади мікроциркуляції, що на субмікроскопічному рівні проявляється сладжами та стазами формених ементів крові у розширених просвітах синусоїдів, ушкодження ультраструктури ендотеліальних клітин, розширені окремі канальці ендоплазматичної сітки, вакуолі й канальці комплексу Гольджі, поодинокі мітохондрії із гомогенним, світлим матриксом і лізованими кристами, розширені простори Діссе, в яких наявні клітини Купфера, просвітлена,
Ultrastructural changes in the liver in experimental hyperhomocysteinemia on the background of hypoand hyperthyroidism

V. M. Nechiporuk ${ }^{1}$, Z. M. Nebesna ${ }^{2}$, O. V. Kovalchuk ${ }^{1}$, L. O. Pentiuk ${ }^{1}$, M. M. Korda ${ }^{2}$

M. Pyrohov Vinnytsia National Medical University I. Horbachevsky Ternopil National Medical University

e-mail: nechiporuk@vnmu.edu.ua

Summary. Thyroid hormones play a crucial role in maintaining metabolic homeostasis throughout life. It is well known that the liver and thyroid gland are closely related, with thyroid hormones playing an important role in de novo lipogenesis, beta-oxidation of fatty acids, cholesterol metabolism and carbohydrate metabolism. High levels of circulating homocysteine (HC) (hyperhomocysteinemia $(\mathrm{HHC}))$ are an independent factor in the development of atherosclerosis, induce the completion of the cell cycle, accelerate the aging process, cause apoptosis in endothelial cells and neurons.

The aim of the study - to establish the reorganization of the structural components of the liver under the conditions of simulated HHCy, hyper- and hypothyroidism and their combined effects.

Materials and Methods. Thiolactone HHCy was simulated by administering to animals exogenous $\mathrm{HC}$ in the form of thiolactone at a dose of $100 \mathrm{mg} / \mathrm{kg}$ body weight once a day for 28 days. Hyperthyroidism was simulated by daily administration of L-thyroxine at a dose of $200 \mu \mathrm{g} / \mathrm{kg}$ on day 21, hypothyroidism - daily administration of mercazolyl at a dose of $10 \mathrm{mg} / \mathrm{kg}$ on day 21. Separate groups of animals were administered L-thyroxine and mercazolyl in parallel with HC.

Results. It was found that under the conditions of simulated HHCy, hypo- and hyperthyroidism in the liver of experimental animals there are disorders of microcirculation, which at the submicroscopic level were manifested by sludge-phenomenon, stasis of blood cells in dilated lumens of sinusoids, damage of the endothelial cells ultrastructure, of some endoplasmic reticulum tubules, vacuoles and dilated cysterns of the Golgi complex, mitochondria were solitary with homogeneous, light matrix and lysed crystae, Disse spaces were mostly expanded, they had Kupffer cells, cytoplasm of sinusoid endothelial cells was enlightened, swollen and destructively changed, and the blood cells and vacuole-like structures were present in the lumen of sinusoids. 
набрякла та деструктивно змінена цитоплазма ендотеліоцитів синусоїдів, в просвітах яких наявні фрормені елементи крові, вакуолеподібні структури.

Висновки. Результати дослідження показали, що і ГГЦ, і гіпо- чи гіпертиреоз окремо та особливо їх поєднання зумовлюють розвиток деструктивних та некротичних змін у печінці. Розвиваються незворотні ушкодження компонентів ядер та органел гепатоцитів, що призводить до порушення синтетичних, енергетичних та детоксикаційних процесів у печінці.

Ключові слова: гіпертиреоз; гіпотиреоз; гіпергомоцистеїнемія; печінка.

\section{ВСТУП}

Гормони щитоподібної залози є регуляторами клітинного розвитку, росту та обміну речовин у ссавців [24] та контролюють ряд метаболічних процесів у клітинах, пов'язаних з анаболізмом або катаболізмом макромолекул, включаючи вуглеводи, білки, ліпіди [11]. Дисбаланс рівнів тиреоїдних гормонів в організмі пов'язаний із множинними хронічними захворюваннями, включаючи цукровий діабет, серцево-судинні захворювання та печінкові розлади [7]. Печінка бере участь у синтезі білків-носіїв та метаболізмі різних гормонів. Хвороби печінки поширені в усьому світі, у тому числі й Україні зростатимуть у майбутньому [18]. Було показано, що захворювання печінки пов'язані 3 різними ендокринними порушеннями [14]. Печінка відіграє важливу роль у метаболізмі гормонів щитоподібної залози та статевих залоз, таких, як кон'югація, екскреція, перифрерійне йодування та синтез тиреоглобуліну та глобуліну, що зв'язує статеві гормони [20]. При різних хворобах печінки порушується фрункція щитоподібної залози, що пов'язана з тяжкістю захворювання печінки. Було встановлено, що гостра печінкова недостатність, пов'язана зі збільшенням циркулюючих ендотоксинів та прозапальних медіаторів і цілком схожа на клінічний стан сепсису, призводить до дисфункції залоз внутрішньої секреції, зокрема до еутиреоїдного синдрому та гіпогонадизму [10, 25]. Також було показано, що стан гіпотиреозу при стабільному цирозі печінки корелює із повільним прогресуванням стадії цирозу, а фрункції щитоподібної залози та статевих залоз покращуються після трансплантації печінки.

Відомо, що гомоцистеїн (ГЦ) є атерогенним та тромбогенним фрактором ризику [13]. ГЦ - це сірковмісна амінокислота, яка в основному синтезується та катаболізується в печінці [19]. Його підвищена концентрація в крові може сприяти судинним ускладненням, пов'язаним з цирозом печінки. Велика кількість доведень показує, що ГЦ опосередковує серцево-судинні проблеми, впливаючи на серцево-судинний ендотелій та клітини гладких м'язів [12]. Існують дані, які підтверджують, що ГЦ може брати участь у розвитку фріброзу печінки [3]. Зміна концентрації ГЦ, ймо-
Conclusions. Both HHCy and hypo- or hyperthyroidism separately and especially under the conditions of their synergistic action caused the presence of "light" and "dark" hepatocytes in the liver lobules, as a manifestation of adaptive-compensatory, destructive and development of necrotic changes in the body. Irreversible damage to the components of the nuclei and organelles of hepatocytes develops, which leads to disruption of synthetic, energetic and detoxification processes in cells and, consequently, in the organs.

Key words: hyperthyroidism; hypothyroidism; hyperhomocysteinemia; homocysteine; liver.

вірно, має місце при захворюваннях печінки, оскільки багато ферментів, що беруть участь у метаболізмі ГЦ (метіонінсинтаза, бетаїн-гомоцистеїн-S-метилтрансорераза, цистатіонін- $\beta$-синтази), мають високу активність у печінці (близько 75 \% загальної здатності організму до трансметирування і синтезу ГЦ). Концентрація ГЦ у плазмі залежить: (I) від клітинного синтезу ГЦ з метіоніну через S-аденозил-метіонін та S-аденозил-гомоцистеїн; (II) елімінування ГЦ, що відбувається шляхом транссульфування цистатіоніну до цистеїну; (III) реметилювання ГЦ метіонінсинтазою або бетаїнгомоцистеїн-метилтранссреразою; (IV) клітинного викиду ГЦ у плазму; і (V) виведення ГЦ 3 плазми крові нирками [2].

У наших попередніх дослідженнях показано, що експериментальний гіпотиреоз викликає підвищення вмісту в крові ГЦ, а гіпертиреоз, навпаки, призводить до зниження рівня останнього, що пов'язано зі змінами активності ферментів метаболізму ГЦ, метіоніну та цистеїну [15].

Метою дослідження було встановити реорганізацію субмікроскопічних структурних компонентів печінки за умов змодельованої гіпергомоцистеїнемії, гіпер- та гіпотиреозу та при їх поєднаному впливові.

\section{МАТЕРІАЛИ I МЕТОДИ}

Досліди проведено на 50 безпородних білих щурах-самцях масою 180-200 г. Щурів утримували при стандартному світловому дні на звичайному харчовому раціоні. Усі дослідження було виконано 3 дотриманням вимог гуманного ставлення до дослідних тварин, регламентованих Законом України «Про захист тварин від жорстокого поводження» (№ 3447-IV від 21.02.2006р.) та Європейською конвенцією про захист хребетних тварин, що використовуються для дослідних та інших наукових цілей (Страсбург, 1986).

Усіх тварин поділили на 6 груп: перша - інтактні щури. Цій групі тваринам внутрішньошлунково вводили 1\% розчин крохмалю; друга - тварини з тіолактоновою ГГЦ, яку викликали внутрішньошлунковим 
введенням ГЦ у вигляді тіолактону в дозі 100 мг/кг маси тіла на 1\% розчині крохмалю один раз на добу протягом 28 діб. Дозу, шляхи та тривалість введення тіолактону запозичено з літературних даних, що не викликали загибелі тварин [22]; третя - щури з гіпертиреозом, яким щоденно протягом 21-ї доби вводили внутрішньошлунково L-тироксин в дозі 200 мкг/кг на 1\% розчині крохмалю [15]; четверта - тварини з тіолактоновою ГГЦ, яким щоденно упродовж 21-ї доби вводили внутрішньошлунково L-тироксин в дозі 200 мкг/кг на 1\% розчині крохмалю; п'ята - щури 3 гіпотиреозом, яким щоденно протягом 21-ї доби вводили внутрішньошлунково мерказоліл на 1\% розчині крохмалю в дозі 10 мг/кг маси [15]; шоста - тварини 3 тіолактоновою ГГЦ, яким щоденно упродовж 21-ї доби вводили внутрішньошлунково мерказоліл у дозі 10 мг/кг на 1\% розчині крохмалю. Щурів виводили з експерименту через 24 год після останнього введення обраних речовин. Забір матеріалу для електронномікроскопічного дослідження печінки проводили згідно із загальноприйнятими правилами [8]. Матеріал фріксували у 2,5 \% розчині глютаральдегіду з активною реакцією середовища $\mathrm{pH}$ 7,2-7,4, приготовленому на фоосоратному буфрері. Посторіксацію здійснювали 1 \% розчином чотириокису осмію, після чого проводили його дегідратацію в спиртах і пропілен оксиді та заливали в суміш епоксидних смол. Ультратонкі зрізи, виготовлені на ультрамікротомі LKB-3 (Швеція), забарвлювали 1 \% водним розчином уранілацетату, контрастували цитратом свинцю згідно з методом Рейнольдса та вивчали в електронному мікроскопі ПЕМ-125К.

\section{РЕЗУЛЬТАТИ Й ОБГОВОРЕННЯ}

Результати проведених субмікроскопічних досліджень печінки групи інтактних тварин показали, що в гепатоцитах наявні округлі ядра, які розміщені

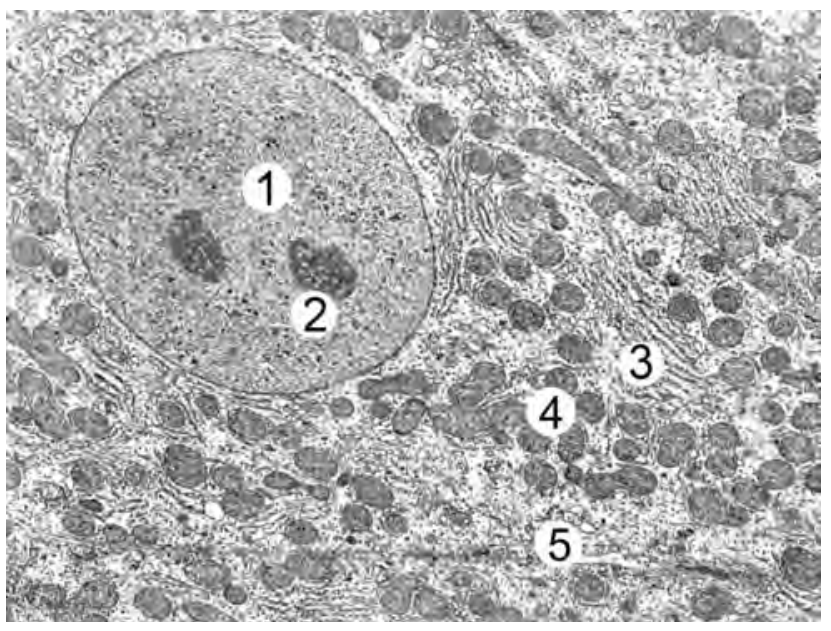

Рис. 1. Ультраструктурна організація гепатоцита печінки тварини інтактної групи: 1 - округле ядро, 2 - ядерце, 3 - канальці ендоплазматичної сітки, 4 - мітохондрії, 5 - жовчний капіляр. ×12 000. переважно в центрі клітини. Мембрани каріолеми чіткі, спостерігається багато ядерних пор. Каріоплазма помірної електронної щільності, визначаються ядерця, що містять фрібрилярний і гранулярний компоненти. Присутні також двоядерні клітини. Цитоплазма гепатоцитів функціонально розподілена, тому наявні ділянки з канальцями гранулярної ендоплазматичної сітки, цистернами комплексу Гольджі, вакуолями, мікропухирцями, мітохондріями та грудками глікогену. По всій площі цитоплазми виявляються поодинокі осміофільні лізосоми, пероксисоми, велика кількість невеликих округлих мітохондрій. Гепатоцити обмежені чіткими плазматичними мембранами, в зонах жовчних капілярів наявні осміофрільні, щільні замикальні контакти та десмосоми, а в просвіті - мікроворсинки (рис. 1).

Поверхня клітин, яка обернена до гемокапіляра, тобто в простір Діссе, містить добре розвинені мікроворсинки. Стінка синусоїдів сформована ендотеліальними клітинами з фенестрованою цитоплазмою та слабовираженою базальною мембраною, яка містить широкі пори (рис. 2).

За умов експериментальної ГГЦ у складі часточок печінки субмікроскопічно встановлено ознаки деструкції паренхіматозних компонентів на тлі судинних розладів. Синусоїдні капіляри мають звужені або розширені просвіти, в яких виявляються стази та сладжі еритроцитів, між якими наявні лімфоцити, нейтрофріли. Цитоплазма ендотеліальних клітин містить незначну кількість змінених органел. Мітохондрії невеликих розмірів, із просвітленим матриксом та частково фррагментованими кристами. Для периферійних цитоплазматичних ділянок характерне зменшення мікропіноцитозних міхурців і кавеол, люменальна поверхня ендотеліоцитів нечітка, містить мало невисоких мікроворсинок. Ядра клітин овальної фрорми, містять в каріо-

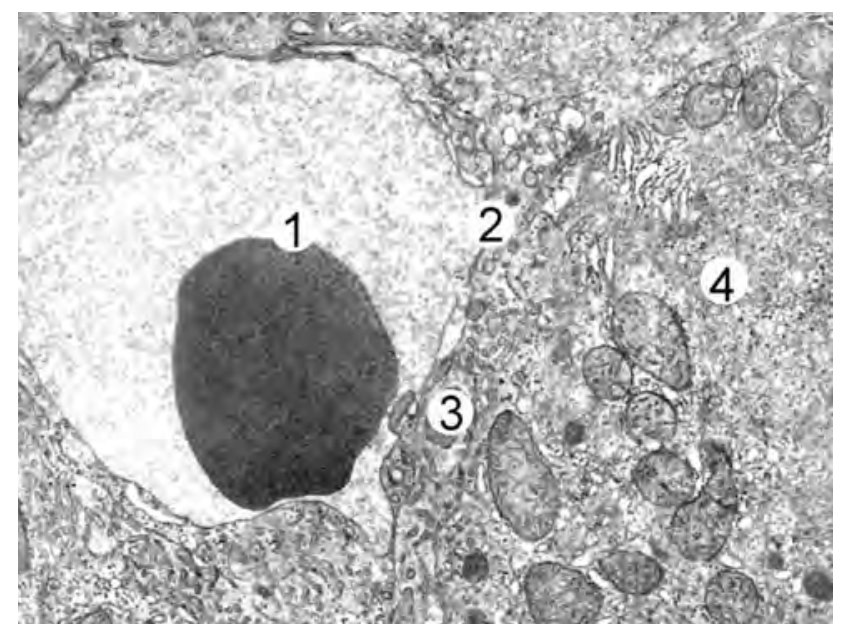

Рис. 2. Ультраструктурна організація гемокапіляра печінки тварини інтактної групи: 1 - просвіт капіляра із еритроцитом, 2 - цитоплазма ендотеліоцита, 3 - простір Діссе 3 мікроворсинками, 4 - цитоплазма гепатоцита. $\times 17000$.
ISSN 2706-6282(print) ISSN 2706-6290(online)
Вісник медичних і біологічних досліджень

Bulletin of Medical and Biological Research
$2(8), 2021$ 
плазмі переважно гетерохматин, каріолема нерівна, з інвагінаціями та нечіткими мембранами (рис. 3).

Ушкоджувальний вплив гіпергомоцистеїнемії визначив наявність у стінці та перисинусоїдному просторі активованих макрофрагальних клітин Купфера. Простори Діссе мали звужені й широкі зони, мікроворсинок у них небагато, вони нечіткі.

У часточках органа наявні гепатоцити з локально оптично світлою цитоплазмою, яка бідна на органели. Мембрани плазмолем клітин подекуди гомогенні, нечіткі. Наявне порушення цілості міжклітинних контактів, навіть у ділянці жовчних капілярів, визначається мало мікроворсинок у їх просвітах, вони нечіткі.

Ультраструктурна реорганізація органел проявляється набряком та вакуолізацією мітохондрій із просвітленням матриксу та редукцією крист. Непротяжні та розширені канальці гранулярної ендоплазматичної сітки виявляються переважно навколо ядра, мало рибосом на їх поверхні. Агранулярна ендоплазматична сітка представлена значно потовщеними канальцями, аж до формування великих вакуолей. Виявляється зменшення кількості рибосом, скупчення розеток глікогену також нечисельні. По всій площі клітин виявляються первинні та вторинні лізосоми, пероксисоми. Комлекс Гольджі розміщений у біліарних поверхнях клітин і представлений погано вираженими цистернами та поодинокими міхурцями та вакуолями (рис. 4).

У попередніх гістологічних дослідженнях ми встановили, що ГГЦ також проявляє руйнівний вплив на тканини печінки - викликає гістіо-лейкоцитарну інфрільтрацію перипортальних ділянок, гіперплазію зірчастих клітин, некроз гепатоцитів, фріброз у портальних зонах та навколо центральних вен [16]. Взаємозв'язок між ГГЦ та розвитком цирозу печінки було показано в роботі [6]. Автори встановили, що зміни метаболізму ГЦ в організмі людини можуть бути частково пов'язані

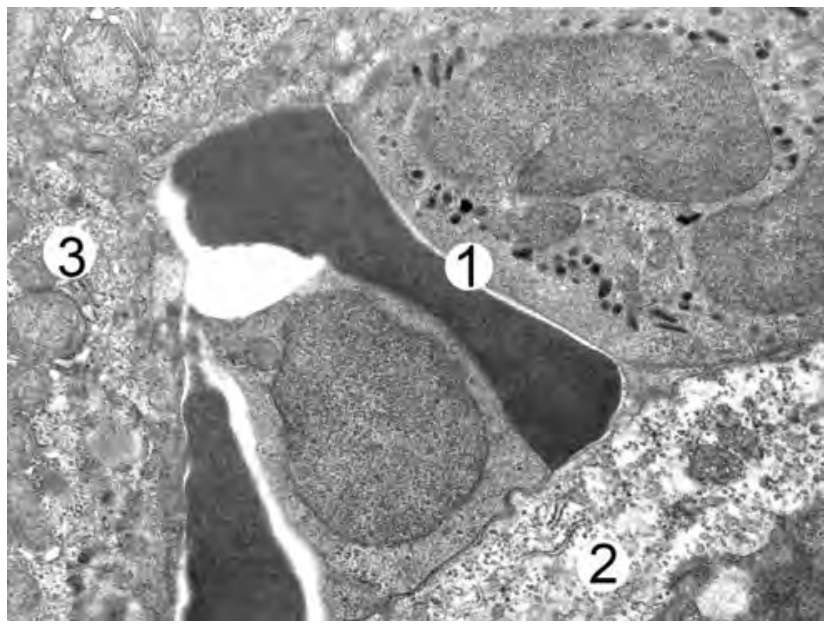

Рис. 3. Ультраструктурні зміни печінки тварини за умов гіпергомоцистеїнемії: 1 - просвіт капіляра з форменими елементами крові, 2 - розширений простір Діссе, 3 - цитоплазма гепатоцита. $\times 17000$.
3 помітним зменшенням експресії основних генів, що беруть участь у його метаболізмі (метіонінсинтази, бетаїнгомоцистеїнметилтрансферази та цистатіонінбетасинтази) та асоціюються з тяжкістю перебігу захворювання печінки. Автори припускають, що порушення метаболізму ГЦ при цирозі може бути пов'язане зі зменшенням доступності або використанням вітамінів $\mathrm{B}_{6}, \mathrm{~B}_{12}$ чи $\mathrm{B}_{9}$. D. Zhang et al., 2015 [29] виявили взаємозв'язок між рівнем циркулюючих фролатів і ГЦ та ризиком розвитку раку печінки. Автори прийшли до висновку, що етнічна приналежність, генетичні поліморфрізми та рівень вітаміну $B_{12}$ сприяють канцерогенезу, а використання фролієвої кислоти для запобігання раку необхідно індивідуалізувати, беручи до уваги дієту, звички, рівень фролату та поліморфрізм MTHFR. У роботі [28] також встановлено, що однією з причин розвитку ГГЦ можуть бути захворювання печінки або її дисорункція, що викликає дисбаланс у внутрішньоклітинному ліпідному обміні. У дослідженні [27] було показано, що ГЦ пригнічує проліферацію гепатоцитів, підвищуючи рівень регулювання білка р53, а також рівні мРНК і білка р21Сір1 у первинних культивованих гепатоцитах. Автори встановили, що протеїни як TRB3 (Tribbles pseudokinase 3), так і p21Cip1 (cyclindependent kinase inhibitor 1) є критично важливими молекулами в сигнальному каскаді обміну ГЦ та забезпечують механістичне пояснення порушення регенерації печінки при ГГЦ.

У печінці тварин за умов експериментального гіпертиреозу також виявляються ознаки порушення ультраструктури клітинних елементів та мікросудин. Гепатоцити містять деструктивно змінену цитоплазму й органели та мають місце порушення субмікроскопічної організації структурних компонентів ядра. Характерним $є$ розширення, фррагментація та вакуолізація канальців ендоплазматичної сітки та цистерн комплексу Гольджі, зменшення кількості пухирців. Більшість мітохондрій збільшена в розмірах, 3

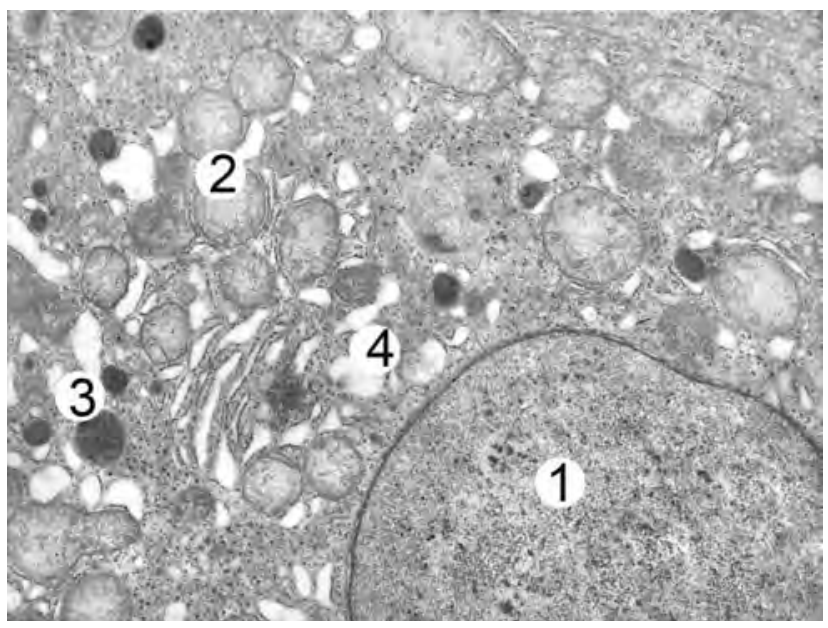

Рис. 4. Субмікроскопічні зміни гепатоцита печінки тварини за умов гіпергомоцистеїнемії: 1 - округле ядро, 2 - мітохондрії, 3 - лізосоми, 4 - розширені канальці ендоплазматичної сітки. ×18 000. 
гомогенним, осміофрільним матриксом та частковим або повним лізисом крист. Про підвищену деструкцію та дистрофрію свідчить зростання числа осміофрільних лізосом та пероксисом в цитоплазмі клітин. Ядра клітин округло-овальної фрорми з нечіткими, нерівними контурами мембран каріолеми та інвагінаціями, утворюються розширені перинуклеарні простори. В каріоплазмі переважає еухроматин, проте наявні осміофрільні скупчення гетерохроматину, рідко виявляються ядерця. Просвіти жовчних капілярів розширені, мікроворсинок мало (рис. 5).

Простори Діссе на певних ділянках значно розширені, в яких мікроворсинки поодинокі або частково редуковані. Виявляються активовані клітини Купфера. Змодельований гіпертиреоз призвів до розладів мікроциркуляції, що на субмікроскопічному рівні проявлявся сладжами, стазами фрормених ементів крові у розширених просвітах синусоїдів, ушкодженням ультраструктури ендотеліальних клітин (рис. 6).

У дослідженні [26] також було відзначено порушення фоннкції печінки у пацієнтів із хворобою Грейвса. Автори встановили, що 65 \% осіб із даною патологією щитоподібної залози мали порушення функцій печінки (гепатоцелюлярні ушкодження та застій жовчі), а найчастішим симптомом була підвищена активність лужної фросоратази. Після лікування щитоподібної залози фрункція печінки нормалізувалась частіше, порівняно з пацієнтами, які не отримували лікування.

За умов поєднаного впливу експериментального гіпертиреозу та ГГЦ встановлено більший ушкоджувальний вплив на субмікроскопічну організацію гепатоцитів порівняно з попередніми групами спостереження. За цих умов наявне значне ушкодження ультраструктури синусоїдів, більшість із них кровонаповнена $з$ проявами тромбоутворення. Ендотеліоцити капілярів мають пікнотичні, осміофрільні ядра, електроннощільну, гомогенну цитоплазму, деструктивно змінені, фррагментовані орга-

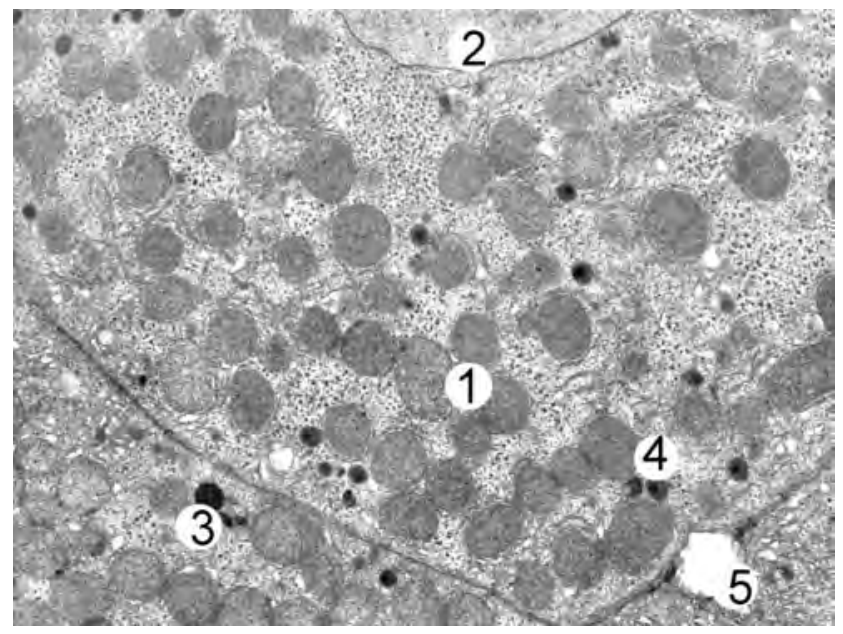

Рис. 5. Субмікрочкопічні зміни печінки тварини за умов гіпертиреозу: 1 - мітохондрії, 2 - фррагмент ядра, 3 - осміосрільні лізосоми, 4 - перексисоми, 5 - жовчний капіляр. ×14000. нели, а в периферійних, цитоплазматичних ділянках небагато мікропіноцитозних міхурців. Простори Діссе в складі стінки гемокапілярів мають значно розширені зони, мікроворсинки в них ушкоджені, нечіткі та нечисельні. В стінці синусоїдів та рідше просторах Діссе визначаються активні макрофраги, клітини Купфера, які містять в цитоплазмі численні осміофільні первинні й вторинні лізосоми (рис. 7).

Виявлені фрагосоми в клітинах вказують на значний патогенний вплив вказаних фракторів на ультраструктуру клітин органа та процеси фогоцитозу та аутолізу.

Для гепатоцитів у складі часточок органа характерні гетерогенні зміни, що проявляються наявністю «темних» клітин із значною осміофрілією цитоплазми та «світлих» 3 просвітленою гіалоплазмою. «Темні» клітини характеризуються глибокими, деструктивними змінами органел. Наявна порушена цілість та фррагментація цистерн комплексу Гольджі та канальців ендоплазматичної сітки. Мітохондрії темні, з електроннощільним матриксом, погано визначаються кристи. Також мало вільних та фріксованих до мембран канальців ендоплазматичної сітки рибосом. Виявляються первинні лізосоми та великі вторинні фагосоми, які визначаються значною мірою у біліарних частинах гепатоцитів. У цитоплазмі також наявні округлої фрорми та нерівномірної осміофільності ліпідні включення (рис. 8). Жовчні капіляри мали звужені просвіти або надміру розширені з поодинокими мікроворсинками.

У «світлому» гепатоциті гіалоплазма оптично просвітлена, бідна на органели. Виявляються окремі канальці ендоплазматичної сітки, вакуолі й розширені канальці комплексу Гольджі, мітохондрії поодинокі з гомогенним, світлим матриксом і лізованими кристами. Цілком вірогідно, що такий напрямок змін у структурних компонентах гепатоцитів може бути пояснений порушенням кровопостачання та мета-

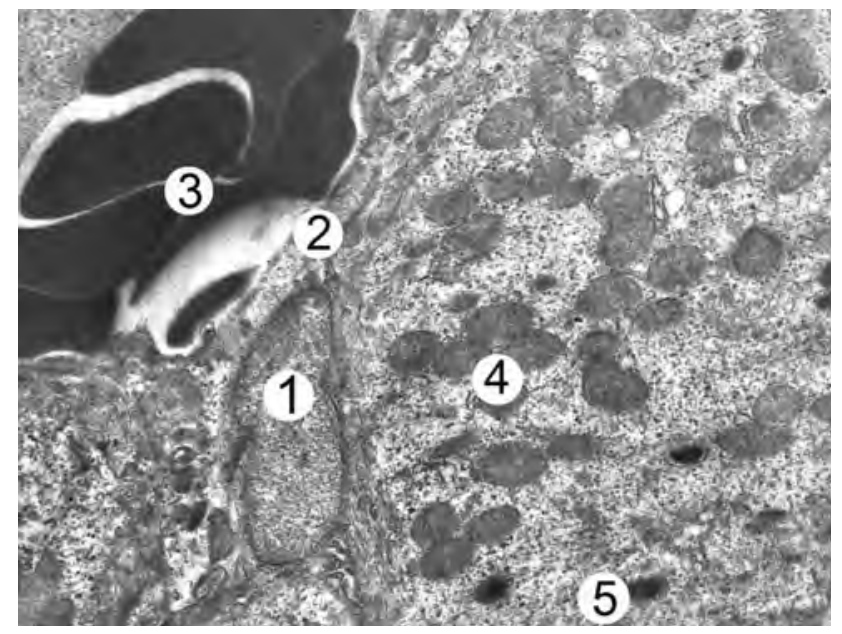

Рис. 6. Ультраструктурні зміни печінки тварини за умов гіпертиреозу: 1 - ядро, 2 - цитоплазма ендотеліоцита, 3 - стаз еритроцитів у просвіті капіляра, 4 - мітохондрії, 5 - пероксисоми. ×14 000.
ISSN 2706-6282(print)

ISSN 2706-6290(online)
Вісник медичних і біологічних досліджень

Bulletin of Medical and Biological Research
$2(8), 2021$ 


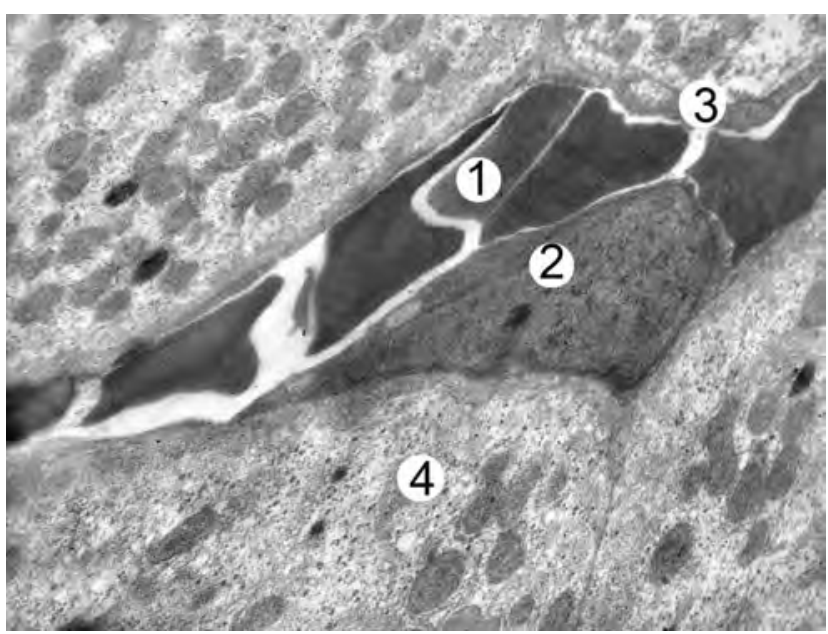

Рис. 7. Ультраструктурні зміни гемокапіляра печінки за умов гіпертиреозу та гіпергомоцистеїнемії: 1 - еритроцити в просвіті капіляра, 2 - пікнотичне ядро, 3 - деструктивно змінена цитоплазма ендотеліоцита, 4 - цитоплазма гепатоцита. ×14000.

болічними затратами печінки, що розвиваються в умовах підвищеного серцевого викиду [9], а правошлуночкова серцева недостатність, викликана тиреогенною міокардіодистрофрією, може посилити ушкодження печінки. Крім того, надлишок тиреоїдних гормонів супроводжується збільшенням мітохондріального обміну через мітофрагію, що призводить до появи мітохондріальних дисффункцій [4]. I. Selicharová et al., 2013 [21] щоб простежити вплив ГГЦ, обробляли гепатоцити розчином ГЦ (0,1 мМ та 2 мМ) та паралельно використовували специфічний інгібітор бетаїнгомоцистеїнметилтрансферази (БГМТ). Автори встановили, що високі концентрації ГЦ 3 паралельним інгібуванням БГМТ призводять до суттєвих дегенеративних змін у протеомах та секретомі гепатоцитів, викликають зростання активності фросфратидилетаноламінкарбоксикінази, орнітин амінотрансорерази, що вказує на втручання ГЦ у метаболічні процеси в клітинах та ураження печінки.

Результати нещодавних досліджень на мишах показали, що підвищений циркулюючий рівень ГЦ асоціюється 3 неалкогольною жировою хворобою печінки (НАЖХП). Було встановлено, що ГЦ викликає неправильне згортання білка в ендоплазматичному ретикулумі. Метіонінова дієта збільшує співвідношення вмісту жиру до маси тіла, зростає рівень тригліцеридів у плазмі крові та знижується рівень ліпопротеїнів високої щільності. Було виявлено, що дієта 3 високим вмістом метіоніну викликає дегенеративні зміни в організмі мишей, а саме, високе співвідношення рівня величини печінки до маси тіла, зростання активності аспартатамінотранссерази та аланінамінотрансорерази, що підтверджувалося морфологічними спостереженнями (накопичення печінкових тригліцеридів у тканині печінки, а також первинних гепатоцитів). Автори прийшли до висно-

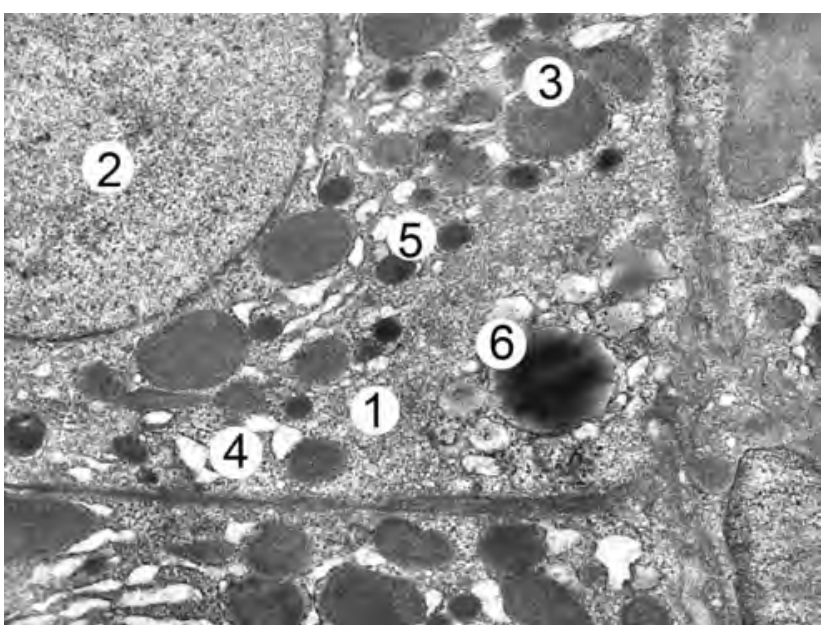

Рис. 8. Ультраструктурні зміни гепатоцитів печінки тварини за умов поєднаного впливу експериментальних гіпертиреозу та гіпергомоцистеїнемії: 1 - електроннощільна гіалоплазма «темного» гепатоцита, 2 - ядро, 3 - осміофрільні мітохондрії, 4 - розширені канальці ендоплазматичної сітки, 5 - лізосоми, 6 - ліпідне включення. $\times 12000$.

вків про те, що підвищений рівень ГЦ є критичним фрактором у патогенезі НАЖХП. Активація реакції на стрес ендоплазматичного ретикулуму може бути пов'язана з індукованим ГЦ стеатозом печінки [1].

Ультраструктура компонентів печінки за умов змодельованого гіпотиреозу також зазнавала змін, що полягають у реорганізації гепатоцитів та гемокапілярів. Цитоплазма клітин неоднорідна, помірної електронної щільності, мітохондрії містять електроннощільний матрикс, нечіткі, фрагментовані або редуковані кристи, деформовану зовнішню мембрану. Канальці гранулярної ендоплазматичної сітки незначно розширені, на їх мембранах нерівномірно розміщені рибосоми, зменшена кількість полісом та включень глікогену в гіалоплазмі. Слабовиражені канальці гладкої ендоплазматичної сітки та цистерни комплексу Гольджі. В цитоплазмі також виявляються ліпідні включення різних розмірів і електронної щільності. В ядрах клітин нуклеоплазма розріджена, гетерохроматин скупчується у вигляді грудок біля каріолеми, яка має нечітко виражені мембрани та нерівномірно розширений перинуклеарний простір (рис. 9). Просвіти жовчних капілярів переважно розширені, проте цілість замикальних контактів збережена, виявляється редукція мікроворсинок.

Простори Діссе також переважно розширені, в них наявні активовані макрофаги - клітини Купфера, в цитоплазмі яких виявляються осміофільні лізосоми та фрагосоми. Цитоплазма ендотеліоцитів синусоїдів просвітлена, набрякла, містить деструктивно змінені, нечисельні органели та мало піноцитозних пухирців і кавеол у периферійних ділянках. У просвітах наявні фрормені елементи крові, вакуолеподібні структури (рис. 10). Встановлено, що у тварин з первинним гіпотиреозом дифузна дрібнокраплинна жирова дистрофрія печінки може бути інтерпретована як наслідок 


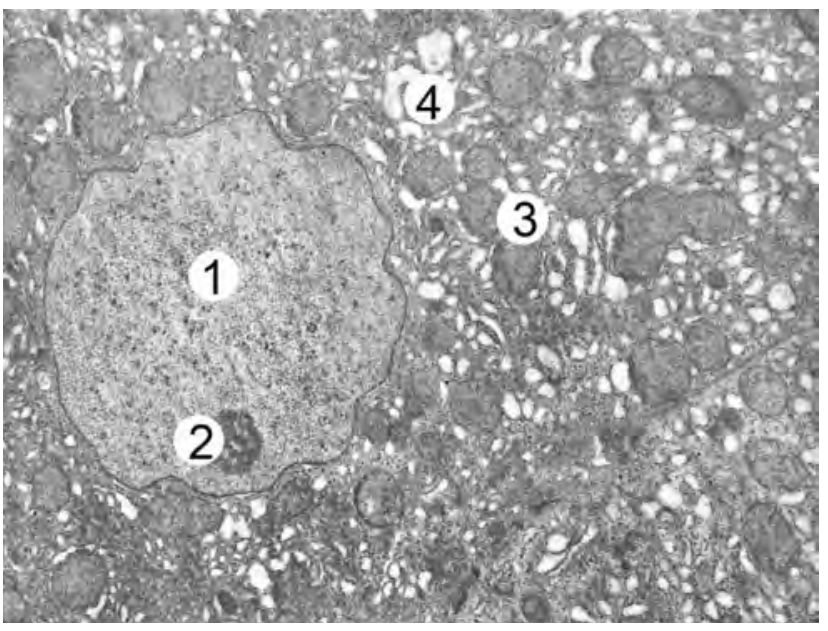

Рис. 9. Ультраструктурні зміни гепатоцитів печінки тварини за умов експериментального гіпотиреозу: 1 - кругле ядро, 2 - ядерце гепатоцита, 3 - мітохондрії, 4 - розширені канальці ендоплазматичної сітки. $\times 17000$

розвитку інсулінорезистентності на тлі зниження функцій щитоподібної залози, що тягне за собою надходження через портальну систему печінки вільних жирних кислот і, як результат, накопичення нейтрального жиру в цитоплазмі гепатоцитів [23]. Ядра клітин мали розріджену нуклеоплазму, гетерохроматин скупчується у вигляді грудок біля каріолеми, має нечітко виражені мембрани з нерівномірно розширеним перинуклеарним простором. Встановлено, що простори Діссе були переважно розширені, в них наявні клітини Купфера. При гіпотиреозі цитоплазма ендотеліоцитів синусоїдів була просвітлена, набрякла та деструктивно змінена, а в просвітах були наявні формені елементи крові, вакуолеподібні структури. Подібні результати отримали також Xuejie Donget al., 2016 [5], які спостерігали у пацієнтів із гіпотиреозом високі рівні ГЦ та ліпопротеїнів низької щільності у плазмі крові. Автори зауважили, що високий рівень ГЦ у плазмі крові при гіпотиреозі позитивно корелює з рівнем холестерину ліпопротеїнів низької щільності. Очевидно, що у пацієнтів із гіпотиреозом підвищення рівня ГЦ є наслідком порушення його обміну та зниження кліренсу нирками через прямий вплив гормонів щитоподібної залози на метаболізм ГЦ у печінці та кліренсу останнього нирками. Лікування левотироксином призвело до значного зниження індексу маси тіла, загального холестерину, ліпопротеїнів низької щільності, тригліцеридів, аполіпопротеїну В та рівня ГЦ. Крім того, зниження рівня ГЦ у пацієнтів з гіпотиреозом позитивно корелювало зі зниженням рівня холестерину ліпопротеїнів низької щільності після лікування левотироксином.

Результати проведених електронномікроскопічних досліджень печінки тварин, яким моделювали гіпотиреоз та ГГЦ, встановили найбільш значні деструктивно-дегенеративні зміни гемокапілярів та клітинних, паренхіматозних компонентів. Виявляють-

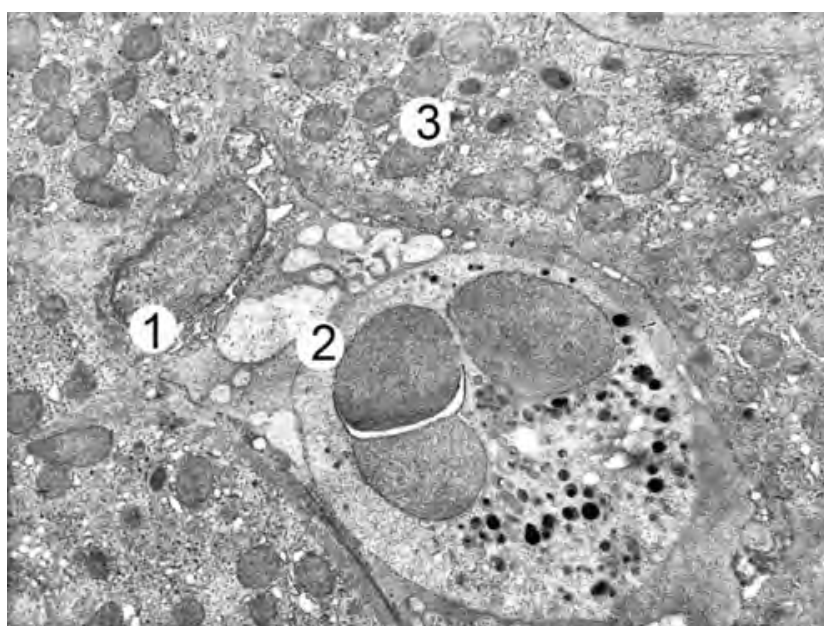

Рис. 10. Субмікроскопічний стан гемокапіляра печінки тварини за умов експериментального гіпотиреозу: 1 - ендотеліоцит, 2 - просвіт капіляра 3 нейтрофільним гранулоцитом, 3 - гепатоцит. $\times 9000$.

ся синусоїдні капіляри, які мають розширені, кровонаповнені просвіти, в яких, крім фрормених елементів крові, наявні великі вакуолі, некротичні маси. Про розвиток альтеративних та дегенеративних змін свідчить збільшення кількості макрофрагальних клітин Купорера в стінці капілярів, у цитоплазмі яких визначаються численні лізосоми та вторинні фрагосоми.

Часто в стінці капілярів спостерігаються значно деструктуризовані ендотеліальні клітини. Ядра клітин осміофрільні, пікнотично змінені, в каріолемі виявляються глибокі інвагінації, визначаються ділянки відмежування зовнішньої мембрани каріолеми. В ядерній зоні виявляються значно змінені, поодинокі, вакуолізовані або фррагментовані органели. У периферійних, цитоплазматичних ділянках - поодинокі мікропіноцитозні міхурці та везикули (рис. 11). Простори Діссе переважно звужені, нечіткі, мікроворсинок мало, вони погано контуруються.

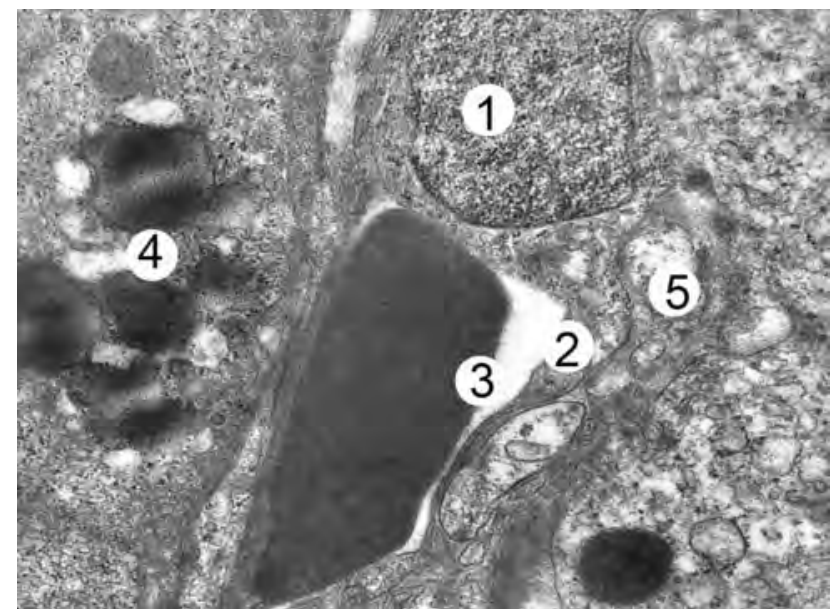

Рис. 11. Субмікроскопічні зміни печінки тварини за умов гіпотиреозу та гіпергомоцистеїнемії: 1 - ядро, 2 - цитоплазма ендотеліоцита, 3 - еритроцит у просвіті капіляра, 4 - ліпідні включення в цитоплазмі гепатоцита, 5 - простір Діссе. ×21 000.
ISSN 2706-6282(print) ISSN 2706-6290(online)
Вісник медичних і біологічних досліджень Bulletin of Medical and Biological Research
$2(8), 2021$ 
Для гепатоцитів характерні поліморфнні зміни, що на субмікроскопічному рівні визначаються наявністю «темних» та «світлих» клітин. Цитоплазма «темних» клітин оптично темна, осміофільна. Органели таких клітин значно змінені, ушкоджені, фррагментовані. В цитоплазмі «світлих» клітин виявляються подинокі органели, вакуолеподібні структури.

Цистерни комплексу Гольджі та канальці ендоплазматичної сітки значно розширені, вакуолізовані, порушена цілість їх мембран. Вільних та фріксованих до мембран канальців ендоплазматичних рибосом мало. Мітохондрії також значно змінені, частина з них гіпертрофована, з електронносвітлим матриксом та лізисом крист. Інші - темні, невеликі за розмірами, з нечіткими кристами. Виявляються численні осміофрільні лізосоми, яких більше в гіалоплазмі «темних» клітин, а також наявні пероксисоми. Цитоплазма гепатоцитів включає жирові включення, різні за розмірами та оптичною щільністю. Ядра клітин округлі, містять нечіткі мембрани каріолеми, із розширеним перинуклеарним простором, в каріоплазмі переважно маргінально розміщений осміофрільний гетерохроматин, практично не визначаються ядерця (рис. 12). Жовчні капіляри були з вузькими, нечіткими просвітами, проте виявлялися капіляри із широкими просвітами, в яких було мало або відсутні мікроворсинки.

\section{ВИСНОВКИ}

Результати проведених субмікроскопічних досліджень печінки показали, що і ГГЦ, особливо ії поєднання з гіпер- чи гіпотиреозом призводять до значних розладів мікроциркуляції та порушення

\section{СПИСОК ЛІТЕРАТУРИ}

1. Homocysteine induces hepatic steatosis involving ER stress response in high methionine diet-fed mice / Y. Ai, Z. Sun, C. Peng [et al.] // Nutrients. - 2017. - Vol. 1, No. 9 (4). - P. 346.

2. Al Mutairi F. Hyperhomocysteinemia: Clinical insights / F. Al Mutairi // J. Cent. Nerv. Syst. Dis. - 2020. - Vol. 12. 1179573520962230.

3. Azzini E. Homocysteine: Its possible emerging role in at-risk population groups / E. Azzini, S. Ruggeri, A. Polito // Int. J. Mol. Sci. - 2020. - Vol. 21 (4). - P. 1421.

4. Molecular functions and clinical impact of thyroid hormone-triggered autophagy in liver-related diseases / H. C. Chi, C. Y. Tsai, M. M. Tsai [et al.] // J. Biomed. Sci. 2019. - Vol. 26 (1). - P. 24.

5. Potential harmful correlation between homocysteine and low-density lipoprotein cholesterol in patients with hypothyroidism / X. Dong, Z. Yao, Y. Hu [et al.] // Medicine (Baltimore). - 2016. - Vol. 95 (29). - P. 4291.

6. Hyperhomocysteinemia in liver cirrhosis: mechanisms and role in vascular and hepatic fibrosis / E. R. GarcíaTevijano, C. Berasain, J. A. Rodríguez [et al.] // Hypertension. - 2001. - Vol. 38 (5). - P. 1217-1221.

7. Thyroid hormones in diabetes, cancer, and aging /

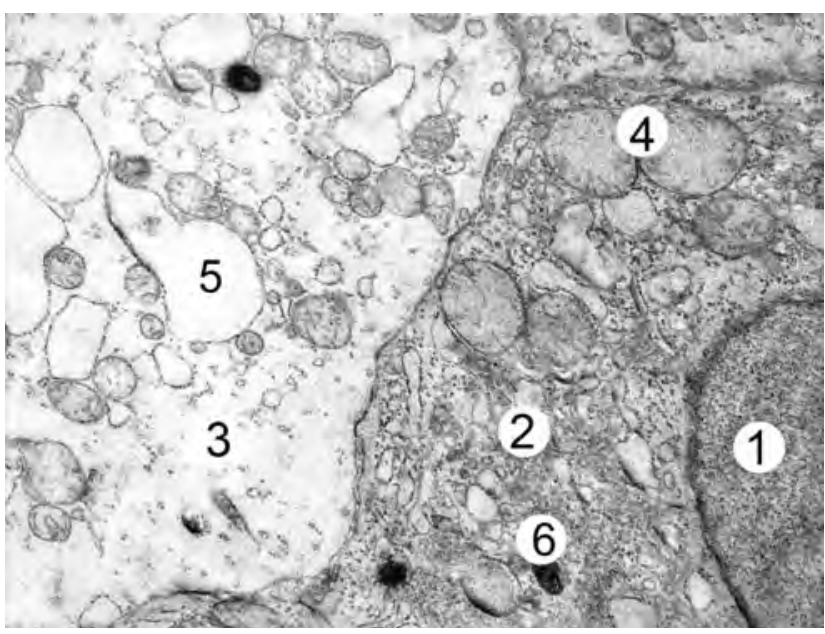

Рис. 12. Ультраструктурні зміни гепатоцитів печінки тварини за умов гіпотиреозу та гіпергомоцистеїнемії: 1 - ядро, 2 - осміофрільна цитоплазма «темного» гепатоцита, 3 - оптично прозора цитоплазма «світлого» гепатоцита, 4 - мітохондрії, 5 - вакуолі, $6-$ лізосоми. $\times 12000$.

транскапілярного обміну, ушкодження ультрастуктурної організації ядер і цитоплазми гепатоцитів, ендотеліоцитів та інших клітинних елементів. Вплив ушкоджувальних чинників окремо та особливо за умов їх синергічної дії зумовив наявність в часточках печінки «світлих» та «темних» гепатоцитів як прояв пристосувально-компенсаторних, деструктивних та некротичних змін в органі. Розвиваються незворотні ушкодження компонентів ядер та органел гепатоцитів, що призводить до порушення синтетичних, енергетичних та детоксикаційних процесів у клітинах, а відповідно й органі.

B. R. Gauthier, A. Sola-García, M. Á. Cáliz-Molina [et al.] // Aging Cell. - 2020. - Vol. 19 (11). - P. 13260.

8. Горальський Л. П. Основи гістологічної техніки і морфоффункціональні методи досліджень у нормі та при патології. - Вид. 3-є, випр. і допов. : навч. посіб. I Л. П. Горальський, В. Т. Хомич, О. І. Кононський ; за ред. Л. П. Горальського. - Житомир : Полісся, 2015. - 286 с.

9. Liver enzyme profile and progression in association with thyroid autoimmunity in Graves' disease / A. Hsieh, S. Adelstein, S. V. McLennan [et al.] // Endocrinol. Diabetes Metab. - 2019. - Vol. 2 (4). - P. 00086.

10. Clinicopathological and biochemical findings of thyroid amyloid in hereditary transthyretin amyloidosis with and without liver transplantation / G. Huang, M. Ueda, M. Tasaki [et al.] // Amyloid. - 2017. - Vol. 24 (1). - P. 24-29.

11. Kalra S. Thyroid dysfunction and dysmetabolic syndrome: The need for enhanced hyrovigilance strategies / S. Kalra, S. Aggarwal, D. Khandelwal // Int. J. Endocrinol. 2021. - Vol. 2021. - P. 9641846.

12. Larsson S. C. Homocysteine and small vessel stroke: A mendelian randomization analysis / S. C. Larsson, M. Traylor, H. S. Markus // Ann. Neurol. - 2019. - Vol. 85 (4). - P. 495-501. 
13. Latteri S. Homocysteine serum levels as prognostic marker of hepatocellular carcinoma with portal vein thrombosis / S. Latteri, G. Malaguarnera, V. E. Catania // Curr. Mol. Med. - 2019. - Vol. 19 (7). - P. 532-538.

14. Lin Y. H. Thyroid hormone in hepatocellular carcinoma: Cancer risk, growth regulation, and anticancer drug resistance / Y. H. Lin, K. H. Lin, C. T. Yeh // Front Med. (Lausanne). - 2020. - Vol. 7. - P. 174.

15. Nechiporuk V. Sulphur-containing amino acids metabolism in experimental hyper- and hypothyroidism in rats / V. Nechiporuk, N. Zaichko, M. Korda // Georgian Med News. - 2017. - Vol. 271. - P. 96-102.

16. Nechyporuk V. Morphological changes of the liver under conditions of hyperhomocysteinemia in the background of hypo- and hyperthyroidism / V. Nechyporuk, M. Korda, O. Kovalchuk // Reports of Morphology [Internet]. - 2020. Vol. 26 (2). - P. 19-25.

17. Metabolism of cysteine in experimental hyper- and hypothyroidism in rats / V. M. Nechyporuk, M. M. Korda // MCCh [Internet]. - 2018. - Vol. 4. - P. 32-40.

18. Netyazhenko $\mathrm{V}$. Thyroid dysfunction and cardiovascular diseases: problem and ways to solve it / V. Netyazhenko, A. Liakhotska // Mìžnarodnij endokrinologìnnij žurnal [Internet]. - 2020. - Vol.16 (4). - P. 333-336.

19. Dysregulated hepatic methionine metabolism drives homocysteine elevation in diet-induced nonalcoholic fatty liver disease / T. Pacana, S. Cazanave, A. Verdianelli [et al.] // PLoS One. - 2015. - Vol. 10 (8). - P. 0136822.

20. A study of thyroid dysfunction in cirrhosis of liver and correlation with severity of liver disease / P. Punekar, A. K. Sharma, A. Jain // Indian J. Endocrinol Metab. - 2018. - Vol. 22(5). - P. 645-650.

21. Effects of hyperhomocysteinemia and betainehomocysteine S-methyltransferase inhibition on hepatocyte metabolites and the proteome / I. Selicharová, M. Kořínek,

\section{REFERENCES}

1. Ai Y, Sun Z, Peng C, Liu L, Xiao X, Li J. Homocysteine induces hepatic steatosis involving $E R$ stress response in high methionine diet-fed mice. Nutrients. 2017;9(4): 346. DOI: 10.3390/nu9040346. PMID: 28368295; PMCID: PMC5409685.

2. Al Mutairi F. Hyperhomocysteinemia: Clinical insights. J Cent Nerv Syst Dis. 2020;12: 1179573520962230. DOI: 10.1177/1179573520962230. PMID: 33100834; PMCID: PMC7549175.

3. Azzini E, Ruggeri S, Polito A. Homocysteine: Its possible emerging role in at-risk population groups. Int J Mol Sci. 2020;21(4): 1421. DOI: 10.3390/ijms21041421. PMID: 32093165; PMCID: PMC7073042.

4. Chi HC, Tsai CY, Tsai MM, Yeh CT, Lin KH. Molecular functions and clinical impact of thyroid hormone-triggered autophagy in liver-related diseases. J Biomed Sci. 2019;26(1): 24. DOI: 10.1186/s12929-019-0517-x. PMID: 30849993; PMCID: PMC6407245.

5. Dong X, Yao Z, Hu Y, Yang N, Gao X, Xu Y, Wang G. Potential harmful correlation between homocysteine and low-density lipoprotein cholesterol in patients with hypothyroidism. Medicine (Baltimore). 2016;95(29): e4291. DOI: 10.1097/MD.0000000000004291. PMID: 27442671; PMCID: PMC5265788.
Z. Demianová // Biochim. Biophys. Acta. - 2013. - Vol. 1834 (8). - P. 1596-1606.

22. Homocysteine thiolactone-induced hyperhomocysteinemia does not alter concentrations of cholesterol and SREBP-2 target gene mRNAS in rats / G. I. Stangl, K. Weisse, C. Dinger [et al.] // Exp. Biol. Med. (Maywood). 2007. - Vol. 232 (1). - P. 81-87.

23. Hypothyroidism-induced nonalcoholic fatty liver disease (HIN): Mechanisms and emerging therapeutic options / D. M. Tanase, E. M. Gosav, E. Neculae [et al.] // Int. J. Mol. Sci. - 2020. - Vol. 21 (16). - P. 5927.

24. Teixeira P. F. D. S. The role of thyroid hormone in metabolism and metabolic syndrome / P. F. D. S. Teixeira, P. B. Dos Santos, C. C. Pazos-Moura // Ther. Adv. Endocrinol. Metab. - 2020. - Vol. 11. - P. 2042018820917869.

25. Liver cirrhosis and thyroid function: Friend or foe? / S. Vincken, H. Reynaert, J. Schiettecatte [et al.] // Acta Clin. Belg. - 2017. - Vol. 72 (2). - P. 85-90.

26. Risk factors of hepatic dysfunction in patients with Graves' hyperthyroidism and the efficacy of 131iodine treatment / R. Wang, J. Tan, G. Zhang [et al.] // Medicine (Baltimore). - 2017. - Vol. 96 (5). - P. 6035.

27. Homocysteine inhibits hepatocyte proliferation via endoplasmic reticulum stress / X. Yu, J. Lv, Y. Zhu [et al.] // PLoS One. - 2013. - Vol. 8 (1). - P. 54265.

28. Hyperhomocysteinemia results from and promotes hepatocellular carcinoma via CYP450 metabolism by CYP2J2 DNA methylation / D. Zhang, J. Lou, X. Zhang [et al.] // Oncotarget. - 2017. - Vol. 8 (9). - P.15377-15392.

29. Elevated homocysteine level and folate deficiency associated with increased overall risk of carcinogenesis: meta-analysis of 83 case-control studies involving 35,758 individuals / D. Zhang, X. Wen, W. Wu [et al.] // PloS One. 2015. - Vol. 10. - P. 0123423.

6. García-Tevijano ER, Berasain C, Rodríguez JA, Corrales FJ, Arias R, Martín-Duce A, Caballería J, Mato JM, Avila MA. Hyperhomocysteinemia in liver cirrhosis: mechanisms and role in vascular and hepatic fibrosis. Hypertension. 2001;38(5): 1217-21. DOI: 10.1161/ hy1101.099499. PMID: 11711526.

7. Gauthier BR, Sola-GarcíaA, Cáliz-Molina MÁ, Lorenzo PI, Cobo-Vuilleumier N, Capilla-González V, Martin-Montalvo A. Thyroid hormones in diabetes, cancer, and aging. Aging Cell. 2020;19(11): e13260. DOI: 10.1111/acel.13260. Epub 2020 Oct 13. PMID: 33048427 ; PMCID: PMC7681062.

8. Goralskiy LP, Homich VT, Kononskiy OI. Fundamentals of histological technique and morphofunctional methods of research in norm and in pathology. [Основи гістологічної техніки і морфоорункціональні методи досліджень у нормі та при патологіï] Zhytomyr: Polissia; 2011. Ukrainian.

9. Hsieh A, Adelstein S, McLennan SV, Williams PF, Chua EL, Twigg SM. Liver enzyme profile and progression in association with thyroid autoimmunity in Graves' disease. Endocrinol Diabetes Metab. 2019;2(4): e00086. DOI: 10.1002/edm2.86. PMID: 31592447; PMCID: PMC6775470.

10. Huang G, Ueda M, Tasaki M, Yamashita T, Misumi Y, Masuda T, Suenaga G, Inoue $Y$, Kinoshita $Y$, Matsumoto $S$, Mizukami M, Tsuda Y, Nomura T, Obayashi K, Ando Y. 
Clinicopathological and biochemical findings of thyroid amyloid in hereditary transthyretin amyloidosis with and without liver transplantation. Amyloid. 2017;24(1): 24-9. DOI: 10.1080/13506129.2016.1276440. Epub 2017 Jan 13. PMID: 28081656.

11. Kalra S, Aggarwal S, Khandelwal D. Thyroid dysfunction and dysmetabolic syndrome: The need for enhanced thyrovigilance strategies. Int J Endocrinol. 2021;29;2021: 9641846. DOI: 10.1155/2021/9641846. PMID: 33859689; PMCID: PMC8024090.

12. Larsson SC, Traylor M, Markus HS. Homocysteine and small vessel stroke: A mendelian randomization analysis. Ann Neurol. 2019;85(4): 495-501. DOI: 10.1002/ana.25440. Epub 2019 Mar 11. PMID: 30785218; PMCID: PMC6594149.

13. Latteri S, Malaguarnera G, Catania VE, La Greca G, Bertino G, Borzì AM, Drago F, Malaguarnera $M$. Homocysteine serum levels as prognostic marker of hepatocellular carcinoma with portal vein thrombosis. Curr Mol Med. 2019;19(7): 532-8. DOI: 10.2174/156652401966 6190610120416. PMID: 31187711.

14. Lin $\mathrm{YH}$, Lin $\mathrm{KH}$, Yeh CT. Thyroid hormone in hepatocellular carcinoma: Cancer risk, growth regulation, and anticancer drug resistance. Front Med (Lausanne). 2020;7: 174. DOI: 10.3389/fmed.2020.00174. PMID: 32528965; PMCID: PMC7258858.

15. Nechiporuk V, Zaichko N, Korda M, Melnyk A, Koloshko O. Sulphur-containing amino acids metabolism in experimental hyper- and hypothyroidism in rats. Georgian Med News. 2017;(271): 96-102. PMID: 29099709.

16. Nechyporuk V, Korda M, Kovalchuk O. Morphological changes of the liver under conditions of hyperhomocysteinemia in the background of hypo- and hyperthyroidism. Reports of Morphology [Internet]. 2020;26(2): 19-25. Available from: https://morphology-journal.com/index.php/journal/article/ view/416.

17. Nechyporuk VM, Korda MM. Metabolism of cysteine in experimental hyper- and hypothyroidism in rats. MCCh [Internet]. 2018;11(4): 32-40. Available from: https://ojs.tdmu. edu.ua/index.php/MCC/article/view/8433.

18. Netyazhenko V, Liakhotska A. Thyroid dysfunction and cardiovascular diseases: problem and ways to solve it. Mìžnarodnij endokrinologì̌nij žurnal [Internet]. 2020;16(4): 333-6. Available from: http://iej.zaslavsky.com.ua/article/ view/208487

19. Pacana T, Cazanave S, Verdianelli A, Patel V, Min HK, Mirshahi F, Quinlivan E, Sanyal AJ. Dysregulated hepatic methionine metabolism drives homocysteine elevation in diet-induced nonalcoholic fatty liver disease. PLoS One. 2015;31;10(8): e0136822. DOI: 10.1371/journal. pone.0136822. PMID: 26322888; PMCID: PMC4556375.

20. Punekar P, Sharma AK, Jain A. A study of thyroid dysfunction in cirrhosis of liver and correlation with severity of liver disease. Indian J Endocrinol Metab. 2018;22(5): 645-50. DOI: 10.4103/ijem.IJEM_25_18. PMID: 30294575; PMCID: PMC6166553.

21. Selicharová I, Kořínek M, Demianová Z, Chrudinová M, Mládková J, Jiráček J. Effects of hyperhomocysteinemia and betaine-homocysteine S-methyltransferase inhibition on hepatocyte metabolites and the proteome. Biochim Biophys Acta. 2013;1834(8): 1596-606. DOI: 10.1016/j. bbapap.2013.05.009. Epub 2013 May 18. PMID: 23689031.

22. Stangl GI, Weisse K, Dinger C, Hirche F, Brandsch C, Eder K. Homocysteine thiolactone-induced hyperhomocysteinemia does not alter concentrations of cholesterol and SREBP-2 target gene mRNAS in rats. Exp Biol Med (Maywood). 2007;232(1): 81-7. PMID: 17202588.

23. Tanase DM, Gosav EM, Neculae E, Costea CF, Ciocoiu M, Hurjui LL, Tarniceriu CC, Floria M. Hypothyroidisminduced nonalcoholic fatty liver disease $(\mathrm{HIN})$ : Mechanisms and emerging therapeutic options. Int J Mol Sci. 2020;21(16): 5927. DOI: 10.3390/ijms21165927. PMID: 32824723; PMCID: PMC7460638.

24. Teixeira PFDS, Dos Santos PB, Pazos-Moura CC. The role of thyroid hormone in metabolism and metabolic syndrome. Ther Adv Endocrinol Metab. 2020;11: 2042018820917869. DOI: 10.1177/2042018820917869. PMID: 32489580; PMCID: PMC7238803.

25. Vincken S, Reynaert H, Schiettecatte J, Kaufman L, Velkeniers B. Liver cirrhosis and thyroid function: Friend or foe? Acta Clin Belg. 2017;72(2): 85-90. DOI: 10.1080/17843286.2016.1215641. Epub 2016 Aug 24. PMID: 27553585 .

26. Wang R, Tan J, Zhang G, Zheng W, Li C. Risk factors of hepatic dysfunction in patients with Graves' hyperthyroidism and the efficacy of 131iodine treatment. Medicine (Baltimore). 2017;96(5): e6035. DOI: 10.1097/MD.0000000000006035. PMID: 28151911; PMCID: PMC5293474.

27. Yu X, Lv J, Zhu Y, Duan L, Ma L. Homocysteine inhibits hepatocyte proliferation via endoplasmic reticulum stress. PLoS One. 2013;8(1): e54265. DOI: 10.1371/journal. pone.0054265. Epub 2013 Jan 22. PMID: 23349842; PMCID: PMC3551933.

28. Zhang D, Lou J, Zhang X, Zhang L, Wang F, Xu D, Niu N, Wang Y, Wu Y, Cui W. Hyperhomocysteinemia results from and promotes hepatocellular carcinoma via CYP450 metabolism by CYP2J2 DNA methylation. Oncotarget. 2017;8(9): 15377-92. DOI: 10.18632/oncotarget.14165. PMID: 28030819; PMCID: PMC5362492.

29. Zhang D, Wen X, Wu W, Guo Y, Cui W. Elevated homocysteine level and folate deficiency associated with increased overall risk of carcinogenesis: meta-analysis of 83 case-control studies involving 35,758 individuals. PloS one. 2015;810: e01234 